УДК 334.021

DOI: $10.25198 / 2077-7175-2020-6-40$

\title{
EXPORT OF ENTREPRENEURIAL CULTURE: CASE STUDIES FROM FINLAND AND GERMANY
}

\author{
A. B. Ilin \\ Bauman Moscow State Technical University, Moscow, Russia \\ e-mail: ilandeducation@yandex.ru \\ Yu. S. Sizova \\ Plekhanov Russian University of Economics, Moscow, Russia \\ e-mail: Sizova.YS@rea.ru, ju-si@mail.ru
}

\begin{abstract}
Relevance: one of the accumulation key areas of macroeconomic stability - entrepreneurial activity, faced country's insurmountable difficulties in 2020. Supporting the business sustainability, it is ready to overcome these difficulties only with the participation of the parties concerned. First of all, entrepreneurship support is the authorities responsibity, and it has already come to life in Russia and in other countries of the world. For their future performance, companies will be influenced by the relationship of society to business and by the business participants, such as as founders, owners, employers. It is obvious, that in the conditions of the current coronavirus pandemic some companies face uncertainty, discordance, and they do not accept forced downtime participation in the business processes.

Entrepreneurship support, business support institutions, relationship of companies' entrepreneurial activity and stakeholders formed the conceipt «entrepreneurial culture». The level of its development will depend, on national -cultural characteristics, which will be reflected in the study.

Purpose: to highlight the parametric dilemmas of the national entrepreneurial culture, to evaluate their actions as exemplified by Finland and Germany.

Methods and methodological apparatus of the study: models of entrepreneurial culture: cultural dimensional characters by G. Hofstede; the development model of intercultural sensitivity by M. Bennett; cultural dimensional characters by $F$. Trompenaars and C. Hampden-Turner; parametric dilemmas of the national entrepreneurial culture by Yu. S. Sizova and A. B. Ilyin [6].

Main results: the concept of entrepreneurial culture is defined; the models of entrepreneurial culture and the restrictions on their use are noted; authors dilemmas of entrepreneurial culture and their use in Finland and Germany are presented and the features of entrepreneurial culture of these countries are determined.

Scientific novelty: for the study of entrepreneurial culture, a complex elements that includes the parametric dilemmas of national entrepreneurial culture as the lack of state support - the attendance of state support was defined: «lack of state support - state suppor existance»; «restrictions for non-resident entrepreneurs - neutrality for non-resident entrepreneurs»; «lack of support institutions - support institutions existence»; «noncompliance to national features in doing business - compliance to national features in doing business»; «lack of the laws supporting entrepreneurial activity - availability of laws supporting entrepreneurial activity»; "lack of business controlling by the supervisory authorities - existence of business controlling by the supervisory authorities»; "adverse business environment - conducive business environment».

Practical relevance: the results of the study may be used by enterprises of different levels.

Key words: entrepreneurship, entrepreneurial economics, entrepreneurial culture, parametric dilemmas of culture, entrepreneurial risks.

Cite as: Ilin, A. B., Sizova, Yu. S. (2020) [Export of entrepreneurial culture: case studies from Finland and Germany]. Intellekt. Innovatsii. Investitsii [Intellect. Innovations. Investments]. Vol. 6, pp. 40-47. DOI: 10.25198/2077-7175-2020-6-40.
\end{abstract}

\section{ЭКСПОРТ ПРЕДПРИНИМАТЕЛЬСКОЙ КУЛЬТУРЫ: ПРАКТИЧЕСКИЕ КЕЙСЫ ИЗ ФИНЛЯНДИИ И ГЕРМАНИИ}

\section{А. Б. Ильин}

Московский государственный технический университет имени Н.Э. Баумана, Москва, Россия e-mail: ilandeducation@yandex.ru 


\section{Ю. С. Сизова}

Российский экономический университет имени Г.В. Плеханова, Москва, Россия e-mail: Sizova.YS@rea.ru,ju-si@mail.ru

Аннотация. Предпринимательская деятельность как одно из ключевых направлений аккумуляции макроэкономической стабильности в стране в 2020 году столкнулась с непреодолимыми трудностями. Преодолеть эти трудности бизнес готов только при участии заинтересованных сторон в поддержке устойчивости субъектов предпринимательства. В первую очередь поддержка предпринимательства возлагается на органы власти, что уже осущзествляется как в России, так и в других странах мира. На дальнейшее существование компаний будут влиять такие факторы, как отношение общества к бизнесу, а также непосредственно самих участников бизнеса - учредителей, собственников, сотрудников. Мьл видим, что часть из них в условиях пандемии сталкивается с неопределенностью действий либо несогласием и непринятием ситуации с вынужденным простоем своего участия в бизнес-процессах фирмы. Поддержка предпринимательства, институть поддержки бизнеса, отношение к предпринимательской деятельности общества и стейкхолдеров формируются в такое понятие как «предпринимательская культура». Уровень ее развития будет зависеть, в том числе, от национальных культурных особенностей, что будет отражено в данном исследовании.

Цель: выделить параметрические дилеммы национальной предпринимательской культуры и оценить их реальные действия на примере стран Западной Европьл.

Методы и методический аппарат исследования: модели предпринимательской культуры: культурные параметры Г. Хофстеде; модель развития межкультурной чувствительности М. Беннетта; параметры культуры Ф. Тромпенаарса и Ч. Хампден-Тернера; параметрические дилеммы национальной предпринимательской культуры Ю. С. Сизовой и А. Б. Ильина [6].

Основные результаты: определено понятие предпринимательской культуры; выделены модели предпринимательской культуры и определены ограничения их применения; представлены авторские дилеммы предпринимательской культуры и их применение в Финляндии и Германии, определень особенности предпринимательской культуры этих стран.

Научная новизна: применительно к вопросу исследования предпринимательской культуры определен комплекс элементов, который включает в себя параметрические дилеммы национальной предпринимательской культуры: «отсутствие поддержки государства - наличие поддержки государства»; «ограничения для предпринимателей-нерезидентов» - «нейтралитет для предпринимателей-нерезидентов»; «отсутствие институтов поддержки - наличие институтов поддержки»; «несоблюдение национальных особенностей ведения бизнеса - соблюдение национальных особенностей ведения бизнеса»; «отсутствие законов по поддержке предпринимательской деятельности - наличие законов по поддержке предпринимательской деятельности»; «отсутствие контроля бизнеса со стороны надзорных органов - наличие контроля бизнеса со сторонь надзорных органов»; «неблагоприятная предпринимательская среда - благоприятная предпринимательская среда».

Практическая значимость: результаты исследования могут быть использованы предпринимательскими структурами разньхх уровней.

Ключевые слова: предпринимательство, экономика предпринимательства, предпринимательская культура, параметрические дилеммы культуры, предпринимательские риски.

Для цитирования: Ilin, A. B., Sizova, Yu. S. (2020) [Export of entrepreneurial culture: case studies from Finland and Germany]. Intellekt. Innovatsii. Investitsii [Intellect. Innovations. Investments]. Vol. 6, pp. 40-47. DOI: $10.25198 / 2077-7175-2020-6-40$.

\section{Introduction}

Business entities face insurmountable entrepreneurial risks in a pandemic. Their performance is limited by the state, by the type of economic activitiy, by the demand of population, by the solvency of customers, and by the company sustainability. The entrepreneurial activity is influenced by the national entrepreneurial culture. The latter is determined by the current institutional support of business in the state, by the level of relationship between contractors, by the attitude of society to business. Acts of God (the current pandemic may be referred to them as well) strengthen by the conflict between participants in various processes, in our case business processes, and the ones aimed at strengthening financial support, economic and managerial environment of entrepreneurship in the country.

However, the governments of different countries try to regulate the situation of the pandemic. So, Russian Federation is going to provide support to such industries as catering, tourism, culture, entertainment, automobile, aviation and also to support the companies of domestic services provision.

For example, pandemic-touched entrepreneurs from Finland will be eligible for unemployment ben- 
efits. Also, according to the government bill, all the entrepreneurs will have eligibilities. 160 million euros has been allocated to provide support to Finnish entrepreneurs. This amount is derived from the calculation that 55 thousand entrepreneurs will apply for this financial assistance.

For example, the Finnish company Stockman, founded 158 years ago, is applying for corporate restructuring, which is the last opportunity to avoid bankruptcy. The company announce the pandemic has had a significant impact on the business environment and it has reduced the number of customers. Finnish self-employed entrepreneurs can apply to the municipalities for a payment of 2,000 euros. Similar measures have been taken in Germany to maintain entrepreneurial activity.

So, supporting tools of entrepreneurship will vary depending on the culture of the business environment shaped. The relevance of the study was determined by the essence, features, and the core business culture of the national economics of Finland and Germany.

\section{Discussion}

The diversity of cultures is growing along globalization goes on. In any scenario, this question becomes relevant for all types of companies - small, mediumsized and large businesses. In addition, in academic and business literature cultural diversity is often called an asset of a group, company and society, a source of creativity and environmental sensitivity [1]. Moreover, all the changes in the cultural sphere of doing business are referred to non-technological, and have no universal patterns [15], and this is a really fertile field for investing funds into human assets development, boosting social responsibility of any company [11].

According to R. Rüttingeu, this is a system of jointly hatched and real beliefs and ideas about values, where ideas make it possible to understand what is important for the enterprise, and beliefs - how the enterprise should perform [10]. The phenomenon of diversity can be analyzed at different levels. Theis phenomenon will be considered at the level of such countries or nations as Finland and Germany (national entrepreneurial culture).

Diversity at the company level is often determined by the cultural features of various nations. The pioneer researcher studying the corresponding mechanism was G. Hofstede [8, 9]. He compared cross-cultural groups and companies in 1970-1980. The results of his research showed that national and regional cultural groups influence the behavior of society. A review of cultural compatibility/ non-compatibility helps understand the actions that can eliminate misunderstanding between representatives of different cultures and evaluate their measures. The researches by G. Hofstede are based mainly on his long-term analysis of the situation at IBM. In 1980 he identified the following cultural dimentions:
- «power distance» - a recognized or permissible degree of inequality among people;

- «individualism - collectivism»-describes the degree to which citizens of the country or any organization employees prefer to be free, not being a member of any group;

- «uncertainty avoidance» - the degree to which people in the country prefer order, as the keeping rules;

- «masculinity - femininity» characterizes the degree to which traditional «masculine» values (perseverance, effectiveness, success and competitiveness) prevailed over «feminine» values (the life's quality, relationships, maintenance and care);

- in 1991 the dimension "short-term - long-term orientation» was added - future-oriented values, for example, the desire for savings-making and sustainability;

- in 2010 the dimension «indulgence of desires restrictions» was added - the degree up to which the society allows their members to embrace life and enjoy it.

However, one of this model's drawback is the constant motion of cultures, they are not fixed and static [7].

A similar approach was applied by F. Trompenaars and C. Hampden-Trainer [7, 13, 14]. They interviewed managers of different companies, analyzing their values of work and the life (1997), but their research was broader. Seven dimensions of corporate culture were identified and they concluded that the difference in cultures revealed should be treated with respect. The seven dimensions can be represented as seven dilemmas that should be resolved:

- «common knowledge - personal truth» (What is more important - rules or exceptions based on realtions?);

- «individualism - collectivism» (Do we act as a part ofa group or as separate individuals?);

- «indifference - sensibility» (How do we express emotions?);

- «specific culture - diffuse culture» (Are our work and life interconnected?)

- «achievements - origin» (Do we earn the status through our own achievements or is it given to us by the birth?);

- «time perspective: past, present, future» (Bo we concentrate on the past, on the present or do we look in the future?);

- «internal control - external control» (Do we control our environment or does it control us?).

The main difference between the model and the earlier theories (the theme of culture and its diversity) lies in the fact that selected dimensions are not used to indicate cultural differences. They are starting points for solving dilemmas. All the exceptions should be studied and the scope should be improved to increase efficiency of world law. To boost entrepreneurship it is wise to cresate communities supporting an active and free action. 
According to the business-oriented approach of V. Terpstra and K. David, culture is a studied, separable, insurmountable and interconnected set of symbols that make up classified cultural shells, the meanings of which determine many orientations for members of a certain community. These orientations, taken together, make it necessary to solve the problems that any community must solve if it continues to strive for survival [12].

F. Trompenaars and C. Hampden-Trainer suggested a 4R approach for working with seven dimensions: definition, respect, reconciliation, awareness. The model helps the user to understand cultural attitudes, cultural perspective of colleagues and business partners, especially in cross-cultural environment. The model $4 \mathrm{R}$ contributes to the development of identification skills, collaboration and training.

However, for obtaining better universal rules within society or in science, it is important to analyze each exception in order to check the level of explanationation that this rule may provide.

M. Bennett [4] (the founder of the Intercultural Communication Institute in the USA) worked out an «development model of intercultural sensitivity» (DMIS, 1986), which describes various ways of accepting cultural differences as the negation and the integration:

$$
\begin{array}{ll}
- & \text { «negation»: } \\
- & \text { «protection»; } \\
- & \text { «minimization»; } \\
- & \text { «acceptance»; } \\
- & \text { «adaptation»; } \\
- & \text { «integration». }
\end{array}
$$

According to M. Bennett people are able to perceive cultural differences, if the intercultural experience is comprehended and interpreted. A person goes through different stages of intercultural sensitivity from ethnocentrism (denial and minimization of differences) to ethnorelativism (differences' acceptance, adaptation to differences, integration of differences). P. Levy in his further studies supports Bennet's ideas [3].

By identifying major cultural differences, assumptions about behaviour and relationships can be made, and cultural education tools can be adapted to ensure development within the formed continuum ${ }^{1}$.

All conceptual models presented are based on the individual and corporate cultural principles. However, globally, entrepreneurial culture scales to the national level and accumulates individual and collective characteristics of national entrepreneurial structures. According to L. S. Leontjeva, Yu. S. Sizova, A. B. Ilyin (2018) [2] the entrepreneurial culture is a group of elements creating a business environment at the levels of micro- (level of the business entity), meso- (between partners / contractors) and the macro (at the level of state).

According to the authors, the group of elements includes the following parametric dilemmas of the national entrepreneurial culture (2020):

- «lack of state support-state support existance»;

- $\quad$ «restrictions for non-resident entrepreneurs neutrality for non-resident entrepreneurs»;

- «lack of support institutions - support institutions existance»;

- $\quad$ «non-compliance to national features in doing business - national features compliance in doing business»;

- «illegal support of entrepreneurial activity legal support of entrepreneurial activity»;

- «lack of business controlling by the supervisory authorities - existence of business controlling by the supervisory authorities»;

- «adverse business environment- conducive business environment».

Further on the features of entrepreneurial culture through the model prism on the example of Western Europe countries such as Finland and Germany will be considered.

\section{Characteristics of entrepreneurial culture in Finland and Germany}

In Finland, the sprcifics of entrepreneurial activity is expressed by foreign citizens, doing business without any restrictions. More attention is paid to corporate responsibility in the field of environmental protection. This is expressed through minimizing paper workflow, saving energy and proper waste management. According to Finnish law, it is allowed to organize entrepreneurship in the following forms: private; in the form of partnership; opened or closed Joint-Stock Company with limited liability; cooperatives.

There are a number of prerequisites as the statuses, the minimum capital, the terms of payment, the accounting and reporting. The $26 \%$ of income tax is paid by companies. The income tax is also paid by private entrepreneurs. Finnish companies' hierarchy has a horizontal structure due to the equal rights in communities. Moreover, the Finns do not like excessive control.

Features of Finnish entrepreneurial culture:

- compliance to time agreement;

- performing actions in strict sequence;

- lack of gestures in business communication; people should not speak too loudly or too quickly and give more information than needed;

- exaggeration of capabilities is not acceptable; emotional reassuring does not mean guarantee to the agreement commitment;

Dumetz J. (2012) Cross-Cultural Management Textbook: Lessons from the World Leading Experts in Cross-Cultural Management, CreateSpace Independent Publishing Platform; Student edition (September 5, 2012). - 416 p. 
- $\quad$ the majority of the Finns value specificity and conciseness ("know your partner");

- the Finns study the contracts thoroughly before signing;

- the meeting's informal atmosphere involves a transition to talk about sports or music, but not about the history of both countries;

- it is normal to look at the interlocutor's eyes, the averted look can be meant as dishonesty ("if the Finns look at their shoes, not at the interlocutor's eyes, they still love him");

- it is not recommended to keep hands in pockets;

- $\quad$ if it is about a business meeting and negotiations, excessively expensive clothes will be inappropriate. It is better to stick to the classic style in a simple suit;

you can shake hands at the first acquaintance only; being presented to colleagues, it is better to start the procedure with a women; excluded;

familiarity and touch (pat on the shoulder) are

- $\quad$ it is indecent to interrupt the interlocutor, to gesture, to rise a voice, to manifest violent emotions;

- a visit is perceived as a holiday organized for a significant occasion;

- the Finns avoid speaking on political topics;

- the Finns prefer local products and value the quality of local goods.

Elements of entrepreneurial culture in Finland: politeness, calmness and correctness.

In Germany entrepreneurship is based on a complex tax system, avoiding entrepreneurial risks through the reasonable investment implementation and compliance to punctuality. Two specific features of doing business in Germany are distinguished. The first is the lack of differences between foreign and own capital for exchanging or making financial transactions. The second is the opportunity to do business in Germany notwithstanding the nationality or residence. It is important, that all money transfers would be registered with local banks and entrepreneur should have enough funds.

According to German law, it is allowed to organize entrepreneurship in the following forms: joint-stock companies, limited liability companies, commandites, corporate partnerships.

Features of the German business culture:

- compliance to punctuality, stringency, legibility;

- a business meeting must be perfectly worked out from a professional point of view;

- business meetings must be agreed beforehand; punctuality is vital; lack of punctuality at business meetings will be a disrespectful attitude to partners;

- the German business protocol requires people' strong and short lasting handshake at a meeting and at a farewell;

- official relations also means the distance in communication - the distance of the outstretched arm. The disturbance of distance is an invasion of personal space.; in greetings, it is accepted to shake the companion's hand tightly, looking into his eyes. German business etiquette welcomes the smile and the humor;

- it is accepted to name the companion by the last name; it is also accepted among colleagues

- the Germans prefer to conduct all business negotiations not by telephone, but in business correspondence, moreover, business letters may be writtrn both in German and in English;

- $\quad$ the Germans can distinguish the work from the private life, they rarely invite business partners for dinner at a restaurant or at home;

- $\quad$ it is better to avoid the topics of music, animals and flowers during small talk;

- modesty is not quoted in Germany as in Finland; all the tittles introducing can be used.

The elements of entrepreneurial culture in Germany: clarity and order in everything.

Let us schematize the features of entrepreneurial culture in Finland and in Germany with the cultural dimensions by G. Hofstede; M. Bennett's model of intercultural sensitivity development ${ }^{2}$; cultural dimensions by F. Trompenaars and C. Hampden-Turner [7]; parametric dilemmas of the national entrepreneurial culture by A. B. Ilyin and Yu. S. Sizova [6].

On the whole, Finnish entrepreneurs can count on the state support when it comes to interaction with government authorities. For example, in case some difficulties in establishing a new company in Finland arise, local authorities advise on additional documents and information that should be provided. A reasonable period of time is defined, and it can be extended at the request of the applicant. For contractual obligations to arise between the parties in Finland, using the e-mail is quite enough. Moreover, signing of the contract in paper is not strictly required. It should be noted that several companies' existence under the same company name is totally impossible in Finland. The rejection of corruption, high standards and principles of corporate governance help Finnish entrepreneurs to achieve their goals and disseminate best business practices, having a beneficial effect, for example, on Russian business environment.

Professionalism plays an important role in German entrepreneurial culture. It requires considerable self-discipline and self-control. Managers in German

Bennett M. J. (2013) Basic Concepts of Intercultural Communication: Paradigms, Principles and Practices, 2nd edn, London, Nicholas Brealey Publishing. -228 p. 
companies earn credibility based on their professional skills. All rules are precisely defined and documented. Reliability and predictability of the organization's pro-

ductivity is provided by written rules, prudence, formal registration, clarity and strict subordination.

Table 1. Entrepreneurial Culture in Finland and Germany

\begin{tabular}{|c|c|c|}
\hline Cultural dillemas & Finland & Germany \\
\hline \multicolumn{3}{|c|}{ Model by G. Hofstede } \\
\hline «power distance» & low degree of distance & hierarchy \\
\hline «individualism - collectivism» & collectivism & individualism \\
\hline «uncertainty avoidance» & high degree of planning & avoiding enterprinurial risks \\
\hline «masculinity or femininity» & egalitarian culture (equality) & masculinity \\
\hline $\begin{array}{l}\text { «short-term orientation -long- } \\
\text { term orientation» }\end{array}$ & long-term orientation & long-term orientation \\
\hline «indulgence of desires - restrictions» & indulgence & restrictions \\
\hline \multicolumn{3}{|c|}{ Model by F. Trompenaars and C. Hampden-Turner } \\
\hline «common knowledge - personal truth» & common knowledge & common knowledge \\
\hline «individualism - collectivism» & collectivism & individualism \\
\hline «indifference - Ssnsibility» & indifference & indifference \\
\hline «specific culture - diffuse culture» & specific culture & specific culture \\
\hline «achievements - origin» & achievements & achievements \\
\hline «time perspective: past, present, future» & future & future \\
\hline «internal control - external control» & internal control & internal control \\
\hline \multicolumn{3}{|c|}{ Model by M. Benetta } \\
\hline negation & - & - \\
\hline protection & - & - \\
\hline minimization & - & - \\
\hline acceptance & + & + \\
\hline adaptation & + & + \\
\hline integration & + & + \\
\hline \multicolumn{3}{|c|}{ Model by Yu. S. Sizova and A. B. Ilyin } \\
\hline $\begin{array}{l}\text { «lack of state support - state support } \\
\text { existance» }\end{array}$ & state support existance & existance \\
\hline $\begin{array}{l}\text { «restrictions for non-resident } \\
\text { entrepreneurs - neutrality for non- } \\
\text { resident entrepreneurs» }\end{array}$ & $\begin{array}{l}\text { neutrality for non-resident } \\
\text { entrepreneurs }\end{array}$ & $\begin{array}{l}\text { neutrality for non-resident } \\
\text { entrepreneurs }\end{array}$ \\
\hline $\begin{array}{l}\text { «lack of support institutions - } \\
\text { support institutions existance» }\end{array}$ & support institutions existance & support institutions existance \\
\hline $\begin{array}{l}\text { «non-compliance to national features in } \\
\text { doing business }- \text { national features } \\
\text { compliance in doing business» }\end{array}$ & $\begin{array}{l}\text { national features compliance in doing } \\
\text { business }\end{array}$ & $\begin{array}{l}\text { national features compliance in doing } \\
\text { business }\end{array}$ \\
\hline $\begin{array}{l}\text { «illegal support of entrepreneurial } \\
\text { activity - legal support of } \\
\text { entrepreneurial activity» }\end{array}$ & legal support of entrepreneurial activity & legal support of entrepreneurial activity \\
\hline $\begin{array}{l}\text { «lack of business controlling by the } \\
\text { supervisory authorities - existence of } \\
\text { business controlling by the supervisory } \\
\text { authorities» }\end{array}$ & $\begin{array}{c}\text { lack of business controlling by the } \\
\text { supervisory authorities }\end{array}$ & $\begin{array}{c}\text { lack of business controlling by the } \\
\text { supervisory authorities }\end{array}$ \\
\hline $\begin{array}{l}\text { «adverse business environment - } \\
\text { conducive business environment» }\end{array}$ & conducive business environment & conducive business environment \\
\hline
\end{tabular}

Source: compiled by the authors. 


\section{Conclusion}

To understand entrepreneurial culture as a phenomenon it is vital to take into consideration the fact that culture can both obey laws and norms and be an exception, possess both individualism and collectivism, be accurate and relative, structured and disobey structure. As exemplified by Finland and Germany, these dimensions are either similar or distinct. How- ever, parametric dilemmas according to the authors' model are favorable: availability of state support, neutrality for non-resident entrepreneurs, availability of support institutions, observance of national peculiarities of doing business, availability of laws to support business activities, absence of business control by supervisory bodies, favorable entrepreneurial environment.

\section{References}

1. Leontjeva, L. S., Sizova, Yu. S., Ilyin, A. B. (2017) [National Entrepreneurial culture in Russia: institutional formation mechanisims]. Sovremennaya konkurentsiya [Modern Competition]. Vol. 11. No. 4, pp. 82-92. (In Russ.).

2. Levy, P. (2006) Korporativnaya kul'tura i upravleniye izmeneniyami [Corporate Culture and Change Management]. Moscow: Alpina Business Books, 192 p.

3. Trompenaars, F., Kuberg, P. X. (2020) 100 klyuchevykh modeley i kontseptsiy upravleniya [100 Key Models and Management Conceipts]. 2-nd edition. Moscow: Mann, Ivanov and Ferber, 640 p. (In Russ., trans. from Engl.).

4. Bennett, J. M., Bennett, M. J. (2004) Developing Intercultural Sensitivity: An Integrative Approach to Global and Domestic Diversity, in: Handbook of Intercultural Training, eds. D. Landis, J. M. Bennett, M. J. Bennett, Thousand Oaks, Sage. Avalable at: https://pdfs.semanticscholar.org/95bf/ 57ec378d6f151cfab8799ce48b29a5de9c7b.pdf?_ga=2.16792761.163075475.1590560588-1017235291.1590560588 (acessed: 29.04.2020).

5. Ilyin, A. B., Sizova, Yu. S. (2020) [Entrepreneurial culture of sports business]. Intellekt. Innovatsii. Investitsii [Intellect. Innovations. Investments]. Vol. 4, pp. 45-51. (In Engl.).

6. Hampden-Turner, C. (1995) Stages in the Development of Intercultural Sensitivity and the Theory of Dilemma Reconciliation: Milton J. Bennett and Charles Hampden-Turner`s Approaches Contrasted and Combined, Cambridge, The Judge Institute of Management Studies.

7. Hofstede, G. (1980) Culture's Consequences: International Differences in Work Related Values. Beverly Hills, Sage, 328 p.

8. Hofstede, G, Hofstede, G. L., Minkov, M. (2010) Cultures and Organisations: Software of the Mind. New York, McGraw-Hill, 576 p.

9. Rüttinger, R. (1992) Culture of entrepreneurship. M: ECOM, 240 p. (in Engl., trans.from German).

10. Sizova, Yu. S. (2018) Development of targeted institutional tools for entrepreneurial culture enhancement. In the book: XXXI International Plekhanov Readings, theses of postgraduate reports in foreign languages, pp. 152-158. (in Engl.).

11. Terpstra, V., David, K. (1991) The Cultural Environment of International Business. South-Western Publishing Co., Cincinnati, $\mathrm{OH}, 252 \mathrm{p}$.

12. Trompenaars, F., Hampden-Turner, C. (2010) Riding the Waves of Innovation: Harness the Power of Global Culture to Drive Creativity and Growth, New York, McGraw-Hill, $272 \mathrm{p}$.

13. Trompenaars, F., Hampden-Turner, C. (2012) Riding the Waves of Culture: Understanding Diversity in Global Business. New York, McGraw-Hill, 400 p.

14. Wang, Chun Lan, Sizova, Yulia S. (2019) Entrepreneurial culture and non-technological changes in business. Public Administration E-Journal. Vol. 72, pp. 104-114. (In Engl.).

\section{Information about the authors:}

Andrei Borisovich Ilin, Ph. D in Economics, Associate Professor of the Department Innovative Entrepreneurship, Bauman Moscow State Technical University, Moscow, Russia

ORCID ID: 0000-0002-4055-1814, Researcher ID: M-5928-2016

e-mail: ilandeducation@yandex.ru

Yulia Sergeevna Sizova, Ph. D in Economics, Associate Professor of Humanitarian Training Center, Federal State Budgetary Educational Establishment of Higher Education Plekhanov Russian University of Economics, Moscow, Russia

ORCID ID: 0000-002-7760-6436

e-mail: Sizova.YS@rea.ru,ju-si@mail.ru 
The paper was submitted: 27.05.2020.

Accepted for publication: 23.11.2020.

The authors have read and approved the final manuscript.

\section{Информация об авторах:}

Андрей Борисович Ильин, кандидат экономических наук, доцент кафедры инновационного предпринимательства, Московский государственный технический университет имени Н. Э. Баумана, Москва, Россия

ORCID ID: 0000-0002-4055-1814, Researcher ID: M-5928-2016

e-mail: ilandeducation@yandex.ru

Юлия Сергеевна Сизова, кандидат экономических наук, доцент Центра гуманитарной подготовки, РЭУ имени Г. В. Плеханова, Москва, Россия

ORCID ID: 0000-002-7760-6436

e-mail: Sizova.YS@rea.ru,ju-si@mail.ru

Статья поступила в редакцию: 27.05.2020; принята в печать: 23.11.2020.

Авторы прочитали и одобрили окончательный вариант рукописи. 